\title{
Developing A Model of English Listening Materials Using Total Physical Response Method
}

\author{
Nurliana \\ State Islamic Institute of Palangka Raya \\ Email: nurliana@iain-palangkaraya.ac.id
}

\begin{abstract}
This research was intended to develop a model of English listening materials using Total Physical Response method for the fourth-grade students of SD Negeri 8 Menteng Palangka. Research and Development $(\mathrm{R} \& \mathrm{D})$ was the method used in this research. The procedure of this research consisted of eleven steps adapted from Sugiyono's model: 1) Distributing questionnaires in need assessment, 2) Analyzing the result of questionnaires, 3) Reference of the research, 4) Developing the model of the materials, 5) Validating the model of the materials, 6) Revising the model of the materials, 7) Trying-out of the model, 8) Distributing questionnaires $\&$ interviewing, 9) Analyzing the result of questionnaires \& interview, 10) Revising the tried-out model, and 11) Producing the final version of the materials. The data obtained were analyzed and described qualitatively. The final product of this research was a model of English listening materials using Total Physical Response method consisting of two units with the following topics: 1) Things in Classroom, and 2) Parts of Body and Face. Each unit consisted of eight parts. Each part consisted of three commands. Based on the research findings, it could be concluded that the model of the developed materials was appropriate with the students' needs.
\end{abstract}

Keywords: Materials, Materials Development, Listening, TPR Method, Elementary Students.

\section{Introduction}

Language as a means of communication plays an important role in social relations among human beings. One of the well-known languages is English. English has become an important means of international communication which is learned almost in every country. In Indonesia English is considered as a foreign language. English is taught in almost all levels of school until universities, including elementary schools. There are four English language skills that must be learned by the elementary school students, namely: listening, speaking, reading, and writing. Listening is included as one of the important skills to be learned. Richards and Renandya (2002:239) stated, "Listening is vital in language classroom because it provides input for the learner. Without understanding input at the right level, any learning simply cannot begin”. However, listening to the English language is hard work for the 
elementary school students. The English language has a different accent and pronunciation from the Indonesian language, so it is difficult enough for the students to understand the spoken English words. In this case, the teacher plays an important role to help and facilitate the students in the teaching-learning process. English language learning in urban schools is supported by very complete facilities, highly professional teachers, supporting books, and even urban schools that often provide a special room as an English laboratory room.(Sakka, Aswad, and Fajriani 2018)

One of the ways is providing suitable listening materials for the students. Materials are defined as anything which can be used in language learning, such as textbooks, websites, videos, and so forth (Tomlinson 2012, 143-44). To provide suitable listening materials for the students, materials development is conducted. Materials development is defined as all of the processes used to produce materials for the learning of language (Tomlinson 2012, 13).

In developing suitable materials for the students, it is necessary to consider the students' characteristics in the teaching-learning process. Scoot and Lisbeth (1990: 2-4) stated that the elementary school students love to play and learn well when they enjoy themselves, but they also take themselves seriously and like to think what they are doing is really work. In addition, elementary school students rely on the spoken words and the physical world to convey and understand the meaning. Total Physical Response (TPR) is one of the interesting methods which are appropriate with the students' characteristic as stated previously. In Total Physical Response (TPR) method, the students listen and respond to the spoken commands of the teacher. If they can do the teacher's commands, it means that they know the meaning of the words. Richard and Rodgers (2001:73) stated, "TPR is a language teaching technique built around the coordination of speech and action; it attempts to teach language through physical (motor) activity". In the teachinglearning process using Total Physical Response (TPR) method, the students and the teacher play a different role. The students have the primary roles of the listeners and performers. They listen attentively and respond physically to commands given by the teacher. In another side, the teacher plays an active and direct role. It is the teacher who decides what to teach, who models and presents the new materials, and who selects supporting materials for classroom use. Precisely, the teacher is encouraged to be well prepared and well organized so that the lesson flows smoothly and predictably (Richard and Rodgers, 2001:76). Moreover, Larsen \& Freeman (2000:113) stated that in Total Physical Response (TPR) method the students are the imitators of the teachers' nonverbal model, while the teacher is a director of all of the students' behaviors. Based on the previous statements, it could be known that in the teachinglearning process by using Total Physical Response (TPR) method, the students and the teacher play a different role. The students play the role as the imitators, listeners, and performers because the students have to imitate, listen, and perform the commands which the teacher says. In another side, the teacher plays the role as the director because the 
teacher gives the commands which the students have to listen and do.

Asher in Larsen \& Freeman (2000:116) stated that it is important that students feel successful. Therefore, the teacher should not give new commands too fast. It is recommended that a teacher presents three commands at a time. After the students feel successful with these commands, three more commands can be given. Furthermore, Larsen \& Freeman (2000:116-117) stated that there are three techniques of Total Physical Response (TPR) method: 1) Using commands to direct behavior. At first, to clarify meaning, the teacher performs the actions with the students. Later, the teacher directs the students alone. The students' actions tell the teacher whether or not the students understand; 2) Role Reversal. The students command the selected classmates to perform some actions: and 3) Action Sequence The teacher explains three connected commands by demonstrating the actions in order. The students watch and try to understand the meaning of the connected commands. For example, the teacher gives the students three connected commands, such as point to the door, walk to the door, and touch the door. Then, the students perform the actions in order.

Some previous studies showed that Total Physical Response (TPR) method was good to be used in teaching elementary students. Arifin (2014) revealed that Total Physical Response (TPR) method through imperatives could significantly improve the students' listening and speaking basic skills. In addition, Hidayah (2010) revealed that the students' responses to the implementation of Total Physical
Response (TPR) method were very good. The students enjoyed the teaching-learning process of English. They became more active and enthusiastic about learning English. They also could understand the English lesson easily when they were taught using Total Physical Response (TPR) method. Moreover, Sugito (2007) revealed that Total Physical Response (TPR) method was very useful for teaching listening comprehension to the students. Most of the students could get satisfactory results. Some advantages of using Total Physical Response (TPR) method were: 1) The students memorized and acquired language through actions. It made the students could memorize what being taught in the teachinglearning process longer since the English language they learned was associated with the actions, 2) Total Physical Response (TPR) method could promote students' motivation and encourage students to have a better attitude toward English language learning. The students enjoyed themselves since they could play while studying and 3) In Total Physical Response (TPR) method the English language was directly used in the context.

SD Negeri 8 Menteng Palangka Raya was an elementary school where this research was conducted. The researcher had found some commands of Total Physical Response (TPR) method in the English textbook entitled "Grow with English" used by the fourth-grade students of SD Negeri 8 Menteng Palangka Raya in the teaching-learning process of English. Based on the result of the interview with the English teacher, it could be known that the existing listening materials using Total Physical Response (TPR) method could make the students active in class. However, the total number of commands in each 
unit of the English textbook was not adequate for the students to follow the teaching-learning process well. Each unit of the English textbook only consisted of four commands of Total Physical Response (TPR) method. The example of the commands of Total Physical Response (TPR) method found in Unit 2 Let's Go to School on page 18 in the English textbook entitled "Grow with English" used by the fourthgrade students of SD Negeri 8 Menteng Palangka Raya was shown as follows:

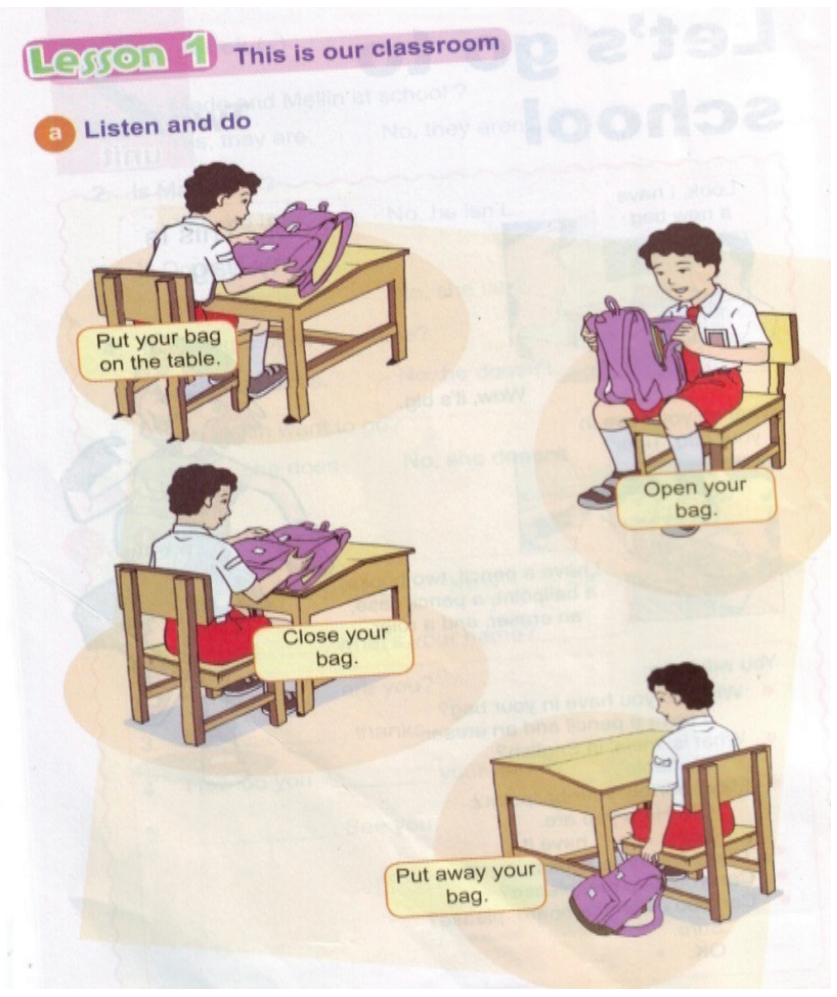

The commands found in Unit 2 were related to Things in Classroom. However, all of the commands found were only related to Table and Bag. There were no commands related to the other things in classroom. Based on the previous statements, it was necessary to develop a model of English listening materials using Total Physical (TPR) method for the fourth-grade students of SD Negeri 8 Menteng
Palangka Raya. Since this research was intended to develop the materials, Research and Development (R\&D) was used in this research. Latief (2016:186) stated that Educational Research and Development is a research used to develop educational products, including curriculum, syllabus, textbooks, media, and so forth. There are various models of materials development. However, in this research the researcher adapted the development model proposed by Sugiyono (2013:298) which consisted of eleven steps: 1) Distributing questionnaires in need assessment, 2) Analyzing the result of questionnaires, 3) Reference of the Research, 4) Developing the model of the materials, 5) Validating the model of the materials, 6) Revising the model of the materials, 7) Tryingout of the model, 8) Distributing questionnaires \& interviewing, 9) Analyzing the result of questionnaires $\&$ interview, 10) Revising the tried-out model, and 11) Producing the final version of the materials.

\section{Findings And Discussion}

The first step of this research was distributing questionnaires in need assessment. In need assessment, the researcher collected the data about the students' needs toward the model of English listening materials. The questionnaires were distributed to 70 students in the fourth grade of SD Negeri 8 Menteng Palangka Raya. The questionnaires were distributed to 38 students of class IV B and 32 students of class IV A. The questionnaires were in the form of closeended questions. The content of the questionnaires was related the students' perception of the existing listening materials using Total Physical Response (TPR) method and the students' demand for the topics of the developed materials. 


\section{a. Analyzing the Result of Questionnaires}

After distributing the questionnaires in need assessment, the researcher analyzed the result of the questionnaires. The result of the questionnaire was tabulated by using percentage. The percentage was converted into qualitative data as follows: $100 \%$ (all), 90-99\% (most of), 80-89\% (a lot of), 50-79\% (many), 30-49\% (some), $1-29 \%$ (few), $0 \%$ (none). The result of the distributed questionnaires was used as the basis to develop the materials. Regarding the students' perception of the existing listening materials, all students (100\%) stated that English listening materials using Total Physical Response (TPR) method were fun. While none of the students (0\%) stated that English listening materials using Total Physical Response (TPR) method was not fun. Furthermore, a lot of the students $(87.14 \%)$ stated they needed more commands of Total Physical Response (TPR) method. While only few students (12.85\%) stated they did not need more commands of Total Physical Response (TPR) method. Concerning with the students' demand for the topics of the developed materials, all students (100\%) thought that the topics of the materials should be interesting. While none of the students $(0 \%)$ thought that the topics of the materials should not be interesting. In addition, many students $(58.57 \%)$ stated that the interesting topics of the materials were Things in Classroom and Parts of Body and Face. While some students (41.42\%) stated that the interesting topics of the materials were Things in Home and Names of Color.
Based on the result of the questionnaires, it could be concluded that the existing English listening materials using Total Physical Response (TPR) method were fun. Therefore, the students needed more commands of Total Physical Response (TPR) method. Regarding the students' demand for the topics of the developed materials, the topics of the materials should be interesting. The interesting topics of the materials were Things in Classroom and Parts of Body and Face.

\section{Reference of the Research}

Reference of the research was done by gathering information related to materials development as the basis of developing English listening materials using Total Physical Response (TPR) method. It was done to develop a suitable model of English listening materials for the students.

\section{Developing the Model of the Materials}

The researcher developed a model of English listening materials using Total Physical Response method for the fourth-grade students of SD Negeri 8 Menteng Palangka Raya in the second semester. The model of English listening materials was developed based on the result of questionnaires in need assessment. The topic in each unit of the materials was based on the students' choice in need assessment. The materials were divided into two units presented in the following topics: 1) Things in Classroom and 2) Parts of Body and Face. Unit 1 (Topic: 
Things in Classroom) consisted of four parts. Each part only consisted of three commands.

Part 1 consisted of three commands as follows:

1. Show me the bag!

2. Show me the pen!

3. Show me the eraser!

Part 2 consisted of three commands as follows:

1. Knock at the door!

1. Show me the pen!

2. Show me the eraser!

Part 3 consisted of three connected commands as follows:

1. Push the chair!

2. Pull the chair!

3. Sit on the chair!

Part 4 consisted of three connected commands as follows:

1. Open the book!

2. Write on the book!

3. Close the book!

Unit 2 (Topic: Parts of Body and Face) consisted of four parts. Each part only consisted of three commands.

Part 1 consisted of three commands as follows:

1. Touch your nose!

2. Touch your cheeks!

3. Touch your forehead!
Part 2 consisted of three commands as follows:

1. Pat your thigh!

2. Bend your knees!

3. Stomp your foot!

Part 3 consisted of three connected commands as follows:

1. Point to your eyes!

2. Close your eyes!

3. Open your eyes!

Part 4 consisted of three connected commands as follows:

1. Raise your hands!

2. Wave your hands!

3. Clap your hands!

Validating the Model of the Materials

In validating the model of the developed materials the researcher distributed questionnaires to two validators. Both validators were the English lecturers of University of Palangka Raya. The questionnaires used in validation were in the form of close-ended questions and open-ended questions. The validators were asked to evaluate the developed model of the materials. The aspects validated were the letter, the organization of the materials, topic, the instruction, the content of the materials, the vocabulary, and the grammar of the developed model of the materials. The result of validation showed the strengths, weaknesses, and suggestions of the developed model of the materials. Both validators stated that the overall 
developed materials were good. The strengths of the developed materials were as follows:

- The letters were clear and readable.

- The organization of materials in the form of units was consistent.

- The materials were organized attractively.

- The topics were appropriate with the students' needs.

- The instruction was clear.

- The instruction was simple and easy to understand

- The content of the materials was in accordance with the learning Indicators.

- The content of the materials was in accordance with Total Physical Response (TPR) method.

- The content of the materials was interesting.

- The content of the materials was arranged well.

- The vocabularies used in the materials were suitable for the students' level.

- The grammatical structures in the materials were correct and meaningful.

However, the weakness was also found in the developed materials. The total number of commands of Total Physical Response (TPR) method was still not sufficient to fulfill some meetings of the try-out process. The writer was suggested to provide more commands of Total Physical Response (TPR) method in each unit of the materials, so the developed materials could fulfill six or eight meetings of the try-out process.

\section{Revising the Model of the Material}

After the model of the developed materials was evaluated by both validators, the model of the materials was revised. Based on the validators' comments and suggestions toward the model of the materials, more commands of Total Physical Response (TPR) method were added and the organization of the materials in each unit was changed, so the materials could fulfill eight meetings of the try-out process.

\section{Try-Out of the Model}

The try-out of the developed model of the materials was conducted in eight meetings. There were totally four lesson plans for eight meetings of the try-out process. The try-out process was done four times in class IV B and four times in class IV A.

\section{Distributing Questionnaires and Interviewing}

After trying-out of the model, the researcher distributed questionnaires to the students and interviewed the English teacher. The questionnaires were distributed to 32 students of class IV A class and 38 students of class IV B. The distributed questionnaires were in the form of a mix of open-ended and closed ended questions. The questionnaires were distributed in order to investigate the students' perception of the developed model of English listening materials. After distributing questionnaires to the students, the researcher interviewed the English teacher of the fourth-grade of SD Negeri 8 Menteng 
Palangka Raya. Semi-structured interview was used in this research. The interview was done in order to investigate the teacher's perception of the developed model of English listening materials.

\section{Analyzing the Result of Questionnaires and Interview}

The result of the questionnaires was tabulated by using percentage. The percentage was converted into qualitative data as follows: 100\% (all), $90-99 \%$ (most of), $80-89 \%$ (a lot of), $50-79 \%$ (many), 30-49\% (some), 1-29\% (few), $0 \%$ (none), while the result of interview was analyzed and described qualitatively. The result of questionnaires and interview was used as the basis to do the revision.

\section{The Result of Questionnaires}

The result of questionnaires was shown below:

- All students (100\%) stated that the materials were easy to understand. While none of the students $(0 \%)$ stated that the materials were not easy to understand.

- All students (100\%) stated that they did not find any difficulties in doing the given commands. While none of the students $(0 \%)$ stated that they found some difficulties in doing the given commands.

- All students (100\%) stated that they did not feel stressed out with the given materials. While none of the students $(0 \%)$ stated that they felt stressed out with the given materials.

- All students (100\%) stated that the materials were interesting and fun. While none of the students $(0 \%)$ stated that the materials were not interesting and fun.

- All students (100\%) stated that the materials could make them motivated in learning English. While none of the students (0\%) stated that materials could not make them motivated in learning English.

Based on the result of questionnaires, it could be concluded as follows:

- The materials were easy to understand because the students were just asked to listen and do the teacher's commands.

- The students did not find any difficulties in doing the commands because the commands were easy to do.

- The students did not feel stressed out with the given materials because the materials were fun and easy.

- The materials were interesting and fun because all of the students did many body movements to do the commands.

- The materials could make the students motivated in class because the materials were fun, interesting, not boring, and easy to understand and do. 


\section{The Result of Interview}

The result of the interview was shown as follows:

- The total number of commands of Total Physical Response (TPR) method was adequate for the students to follow the teaching-learning process well.

- English listening materials using Total Physical Response (TPR) method were interesting and fun for the students. The students just did the body movements as the responses whether they understood or not the commands that they listened, so the students could learn English easily.

- The given materials could arouse the students' motivation in learning English. The students liked this kind of materials because of learning English by doing. The materials could make the students easy to understand English lesson.

- The materials were useful to develop the students' English listening skill.

- Based on what the teacher observed in the teaching-learning process of English, the application of the overall materials was good. The given materials could make all of the students active in class.

\section{Revising the Tried-Out Model}

Based on the results of questionnaires and interview obtained after the try-out process, it could be known that it was not necessary to do any revision toward the materials. The materials were applicable for the students in the teachinglearning process of English.

\section{Producing the Final Version of the Materials}

After doing validation, revision, and try-out process, the final version of the second semester English listening materials using Total Physical Response (TPR) method for the fourth-grade students of SD Negeri 8 Menteng Palangka Raya was produced. The final version of the materials consisted of two units with the following topics:

1) Things in Classroom and 2) Parts of Body and Face. Unit 1 (Topic: Things in Classroom) consisted of eight parts. Part 1 consisted of three commands as follows:

1. Show me the bag!

2. Show me the pen!

3. Show me the eraser!

Part 2 consisted of three commands as follows:

1. Knock at the door!

2. Point to the window!

3. Touch the table!

Part 3 consisted of three connected commands as follows:

1. Open the book!

2. Write on the book!

3. Close the book!

Part 4 consisted of three connected commands as follows:

1. Push the chair!

2. Pull the chair!

3. Sit on the chair! 
Part 5 consisted of three commands as follows:

1. Show me the pencil!

2. Show me the sharpener!

3. Show me the ruler!

Part 6 consisted of three commands as follows:

1. Touch the pencil case!

2. Point to the map!

3. Look at the clock!

Part 7 consisted of three connected commands as follows:

1. Touch the whiteboard!

2. Write on the whiteboard!

3. Clean the whiteboard!

Part 8 consisted of three connected commands as follows:

1. Point to the floor!!

2. Sweep the floor!

3. Mop the floor!

Unit 2 (Topic: Parts of Body and Face) consisted of eight parts.

Part 1 consisted of three commands as follows:

1. Touch your nose!

2. Touch your cheeks!

3. Touch your forehead!

Part 2 consisted of three commands as follows:

1. Pat your thigh!

2. Bend your knees!

3. Stomp your foot!
Part 3 consisted of three connected commands as follows:

1. Point to your eyes!

2. Close your eyes!

3. Open your eyes!

Part 4 consisted of three connected commands as follows:

1. Touch your head!

2. Nod your head!

3. Shake your head!

Part 5 consisted of three commands as follows:

1. Touch your elbow!

2. Touch your stomach!

3. Touch your back!

Part 6 consisted of three commands as follows:

1. Show your teeth!

2. Touch your ears!

3. Shake hands!

Part 7 consisted of three connected commands as follows:

1. Raise your hands!

2. Wave your hands!

3. Clap your hands!

Part 8 consisted of three connected commands as follows:

1. Touch your hair!

2. Wash your hair!

3. Comb your hair! 


\section{Conclusion}

Based on the research findings, it could be concluded that the developed model of the listening materials using Total Physical Response (TPR) method was appropriate with the students' needs. Furthermore, the developed model was applicable for teaching listening comprehension to the fourthgrade students of SD Negeri 8 Menteng Palangka.

\section{References}

Arifin, Z., Handayani L., \& Susilawati, E. (2014). Improving Both of Students Listening and Speaking Basic Skills Using Imperative by Total Physical Response (TPR) Technique. Jurnal Pendidikan dan Pengajaran 3 (3), 1-7.

Hidayah, N. (2010). Teaching English to Elementary Student Using TPR Method in SDN Setonorejo. II Kras Kediri (Undergraduate Thesis). State Islamic College of Tulungagung, Tulungagung.

Larsen, D. \& Freeman. (2000). Technique and Principles in Language Teaching ( $\left.2^{\text {nd }} \mathrm{ed}.\right)$. New York: Oxford University Press.

Latief, M. A. (2016). Research Methods on Language Learning: An Introduction. Malang: Malang State University.

Richards, J. C \& Renandya W. A. (2002). Methodology in Language Teaching. An Anthology of Current Practice. Cambridge: Cambridge University Press.
Richards, J. C. \& Rodgers, T. S. (2001). Approach, Method, and Technique for English Language Teaching ( $2^{\text {nd }}$ ed.). Cambridge: Cambridge University Press.

Scoot, W.A. \& Lisbeth H. Y. (1990). Teaching English to Children. New York: Longman.

Sugito. (2007). Teaching Listening Comprehension to The Fourth Graders of Elementary School Students by Using The Total Physical Response Method, A Case of The Fourth Graders of SDN Jinggotan Kembang Jepara in The Academic Year of 2004/2005 (Undergraduate Thesis). Semarang State University, Semarang.

Sugiyono. (2013). Metode Penelitian Pendidikan. Pendekatan Kuantitatif, Kualitatif, dan R\&D. Bandung: Alfabeta.

Tomlinson, B. (2012). Materials Development for Language Learning and Teaching. Language Teaching 45 (2), 143-179.

Sakka, Wahyuni, Muhammad Aswad, and Fajriani Fajriani. 2018. "Enhancement of English Student Learning Results through Total Physical Response (TPR) Method." EDUVELOP (Journal of English Education and Development) 1 (2): 86-95. https:// doi.org/10.31605/eduvelop.v1i2.31.

Tomlinson, Brian. 2012. "Materials Development for Language Learning and Teaching." Language Teaching 45 (2): 143-79. https://doi.org/10.1017/ S0261444811000528. 